\title{
THE CULTURAL LIVES OF LAW
}

\section{Austin Sarat, Editor}

The Cultural Lives of Law series brings insights and approaches from cultural studies to law and tries to secure for law a place in cultural analysis. Books in the series focus on the production, interpretation, consumption, and circulation of legal meanings. They take up the challenges posed as boundaries collapse between as well as within cultures, and as the circulation of legal meanings becomes more fluid. They also attend to the ways law's power in cultural production is renewed and resisted. Among the topics of books in The Cultural Lives of Law series are law and popular culture, legal consciousness, literary analysis of law, the self-understandings of legal actors, celebrated trials, the regulation of artistic and cultural life, and historical and ethnographic treatments of law and national identity. 



\section{W I L L I A M P. MACNEIL}

\section{Lex Populi}

The Jurisprudence of Popular Culture 


\section{Stanford University Press \\ Stanford, California}

(C) 2007 by the Board of Trustees of the Leland Stanford Junior University.

All rights reserved.

No part of this book may be reproduced or transmitted in any form or by any means, electronic or mechanical, including photocopying and recording, or in any information storage or retrieval system without the prior written permission of Stanford University Press.

Printed in the United States of America on acid-free, archival-quality paper

\section{Library of Congress Cataloging-in-Publication Data}

MacNeil, William P.

Lex populi : the jurisprudence of popular culture / William P. MacNeil.

p. cm.- (The cultural lives of law)

Includes bibliographical references and index.

ISBN-13: 978-0-8047-5367-8 (cloth : alk. paper)

ISBN-10: 0-8047-5367-9 (cloth : alk. paper)

1. Culture and law. 2. Sociological jurisprudence. 3. Popular culture. 4. Law-Psychological aspects. I. Title.

K487.C8M33 2007

$340^{\prime} .115-\mathrm{dc} 22$

2006036365

Typeset by Newgen in 10/14.5 Minion Roman 
To my parents,

John Angus and Viberta Marie MacNeil 
